( 7 )

\title{
ハプティックデバイスを用いた下肢の体性感覚-運動 連関機能の評価
}

\author{
速水達也 ${ }^{1}$, 金子文成 ${ }^{2}$, 横井孝志 ${ }^{3}$, 木塚朝博 ${ }^{4}$
}

1信州大学全学教育機構健康科学教育部門, ${ }^{2}$ 札幌医科大学理学療法学第二講座,

産業技術総合研究所, 筑波大学体育系

\begin{abstract}
要旨 本研究では, 体性感覚入力（運動感覚）に基づく運動調節機能を体性感覚-運動連関機能 と定義し, 体性感覚一運動連関機能を測定評価するための運動課題（運動平衡保持課題）を実施 した，運動課題の実施には，作成したハプティックデバイスを使用し, 装置から加わる力との釣 り合いを保ち，身体位置の変化がどの程度生じたかを定量化した。これまでの報告に加えて，装 置から加わる力が漸増する局面と漸減する局面とで，測定結果がどのように異なるかを調べた． さらに, 対象者を運動歴の有無に応じて 2 群に分類し, 運動歴の差異による影響についても検討 した，その結果，漸減する局面の方が漸増する局面に比べて課題の難易度が高く，運動歴による 影響も漸減局面において顕著であることが示された，また，運動平衡保持課題を練習方法として 用い, 両局面の測定結果がどの程度改善されるかについて調べ, 練習の前後で感覚機能と運動機 能とがどのように変化するかについても検証した，その結果，両局面ともに練習期間前後で有意 に改善し，感覚機能と運動機能も向上することが明らかとなった。これらの結果から, ハプティ ックデバイスを使用して実施する運動平衡保持課題は, 体性感覚-運動連関機能の測定評価方法 として妥当であり, 感覚機能と運動機能の向上を目的とした練習方法としても有用である可能性 が考えられた。
\end{abstract}

キーワード：体性感覚-運動連関機能，運動平衡保持課題，感覚機能，運動機能

\section{1.はじめに}

スポーツやリハビリテーションの現場においては, 運動を合目的的に遂行するために，正確性を高め, 新たな運動パターンを獲得するための練習が行われ る。その際には, 感覚情報が重要な役割を持ち, 特 に, 身体各部位の相対的位置関係や関節角度, 力発 揮の程度に関する感覚は運動感覚と定義されてい
る ${ }^{1)}$ ，運動感覚の形成に寄与する感覚受容器は，筋 紡錘やゴルジ腱器官などの体性感覚受容器である ${ }^{2)}$ これまで, 体性感覚受容器からの求心性入力を遮断 した状態での運動調節課題に関する先行研究の結果 から, 感覚遮断を施した状態で到達課題を行うと, 筋出力とそれに伴う関節運動の安定性は低下し，巧 緻性の高い運動の遂行が困難になることが明らかに されている ${ }^{3,4)}$.これらのことは，合目的的な運動 調節において体性感覚受容器からの求心性入力によ 
82 バイオメカニズム 22

り知覚される運動感覚 (感覚機能) と, 安定性の高 い力発揮（運動機能）が影響を及ぼすことを示唆し ていると考えられる。本研究では, この運動感覚知 覚に応じて運動調節する機能を, 体性感覚一運動連 関機能と定義する。

これまでに我々は, 体性感覚 - 運動連関機能の測 定評価方法として，ハプティックデバイス ${ }^{5)}$ 用い た新規運動課題（運動平衡保持課題）を考案した ${ }^{6,7)}$ 運動平衡保持課題の実施時, 対象者は, 閉眼した状 態で装置から加えられる力との釣り合いを保ち，身 体位置の変化を最小限にとどめることを要求される. 我々はこれまでに, 運動平衡保持課題の測定結果が 感覚機能および運動機能の双方を包含していること を示した ${ }^{8)}$ 。また, 運動歴の有無によって測定結果 が異なり，専門競技レベルでのトレーニングを継続 的に行っている者が日頃運動を行っていない者に比 べて測定結果に優れることを報告した ${ }^{9)}$ 。これらの ことは, 運動平衡保持課題が体性感覚一運動連関機 能の測定評価方法として有用である可能性を少なか らず示している.

その一方で, 運動平衡保持課題の実施中に装置か ら加わる力（対象者が釣り合いを保つための目標 力）は常に増減を繰り返すため, 漸増局面と漸減局 面が存在することになる，筋の生理学的機能を考え ると, 筋出力の増減に打いて, 漸増局面と漸減局面 とでは同一運動単位の動員開始（recruitment）お よび停止（de-recruitment）の閥值が異なることが 報告されている ${ }^{10 \sim 12)}$ ，さらに，筋活動を制御する 上位中枢機能として, 漸減局面では皮質脊髄路の興 奮性にヒステリシスが生じることが報告されてい る ${ }^{13)}$ ，これらの報告は，単一筋の活動を考えた場合 に局面間で異なる運動制御を行っていることを示唆 している. したがって, 運動平衡保持課題の実施時 における運動調節も装置から加わる力の漸増局面と 漸減局面とで異なり, 測定結果に相違が認められる 可能性がある.

また，局面間で実施成績が異なり，どちらかの局 面で課題遂行の難易度が高いと仮定すると, その相 違は先に述べた対象者の運動歴の差異 ${ }^{9)} に$ 影響を受 ける可能性が考えられる。
そこで本研究では，まず，運動平衡保持課題にお ける目標力の漸増局面と漸減局面との相違を, 対象 者の運動歴の差異による影響から明らかにすること を目的とした（検討課題 1).

また，運動平衡保持課題を練習介入方法として用 いることを想定した場合, 練習効果が運動平衡保持 課題による測定結果に反映されることが明らかとな れば，当該課題は感覚機能と運動機能の双方を包含 しているため, それにより感覚機能および運動機能 の向上が期待できる可能性がある。このことが明ら かとなれば，運動パフォーマンス向上や転倒予防等 を目的とした，スポーツ現場やリハビリテーション 現場における新たな練習方法の提案に繋がると考え た。ただし，運動感覚の向上は短期間の運動でも急 性的効果を見达めることが報告されている ${ }^{14 \sim 16)} た$ め, 一定期間の介入効果を調べるだけではなく，短 期間での変化についても検証する必要がある.

以上のことから，測定評価方法の詳細な検討とし ての局面間の相違を調べることに加えて，運動平衡 保持課題を練習介入方法として用い, 練習効果を捉 えることができるか検証するとともに，それに伴う 感覚機能および運動機能の変化についても検証する ことを目的とした（検討課題 2).

\section{2. 運動平衡保持課題による測定結果にお ける目標力の漸増および漸減局面の相 違 (検討課題 1)}

検討課題 1 は, これまでに我々が報告したデー 夕 ${ }^{17)} に$ ，新たに測定を実施してデータ数を追加して 解析を行ったものである。

\section{1 対象者}

対象者は, 下肢に既往歴のない成人男性 36 名 $(22.4 \pm 2.3$ 歳, $171.6 \pm 5.2 \mathrm{~cm}, \quad 68.7 \pm 6.8 \mathrm{~kg})$ で あった。そのうち, 大学体育会運動部に所属し, 種 目は問わず様々な専門スポーツ競技経験を少なくと も 3 年 (2 名以外は 6 年) 以上有する 18 名を運動 群とした。また，これまで長期に渡る身体トレーニ ングや専門的なスポーツ競技等を行った経験のない 18 名を対照群とした。測定内容については, 測定 
（7）ハプティックデバイスを用いた下肢の体性感覚-運動連関機能の評価 83

を実施した産業技術総合研究所の倫理委員会で承認 を得た後，対象者から書面で同意を得た。なお，測 定は対象者の安全に十分配慮して行った.

\section{2 運動平衡保持課題の実施手順および解析 項目}

運動平衡保持課題による測定は, 産業技術総合研 究所にて開発されたハプティックデバイスを用いて 行った（図 $1 \mathrm{a}$ )。測定装置上のフットレストは, 測 定装置に内蔵されたモータからアームによって接続 されている.フットレストとアームの接続部に設置 されたセンサーからはカのデー夕 $[\mathrm{N}]$ が取得され る。ささらに、モータの回転角度をエンコーダによっ てフットレストの位置座標 $[\mathrm{mm}]$ として計測し， これらのデータはパーソナルコンピュータに保存す ることができる。なお, 本研究では先行研究 ${ }^{7 \sim 9)}$ と
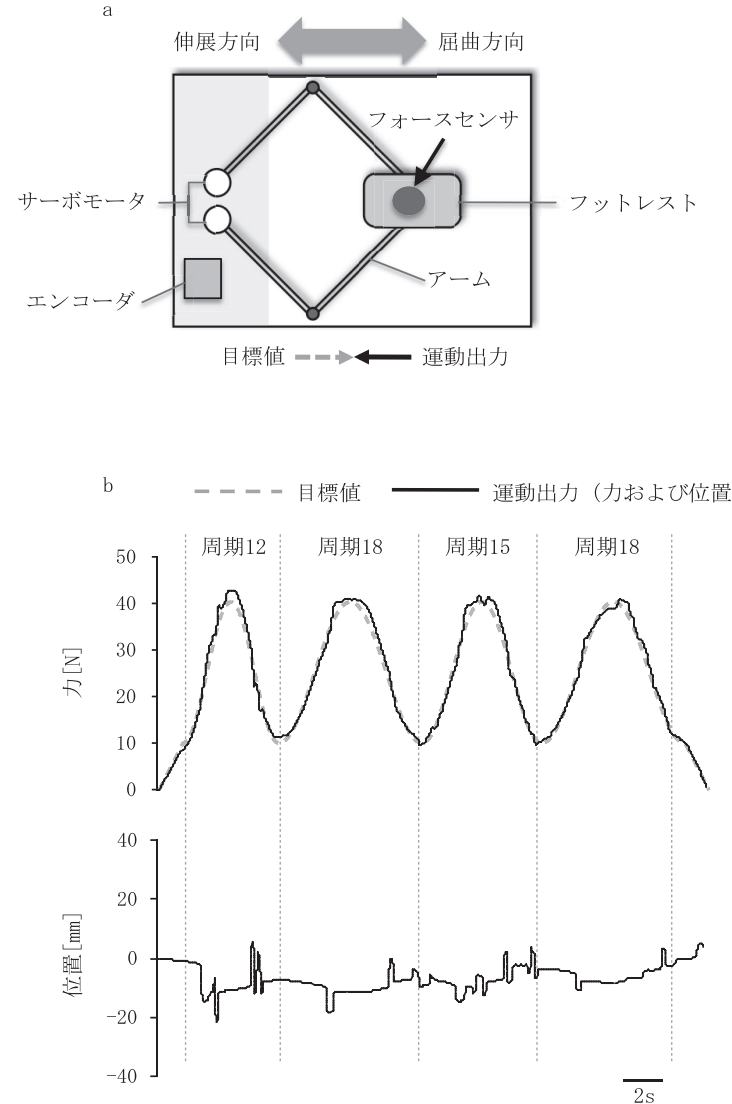

同様に, 力の釣り合いが取れていたか否かが最終的 に反映される，位置座標データを解析した。サンプ リング周波数は $200 \mathrm{~Hz}$ とした。

測定は，対象者に左足をフットレストに乗せるよ う指示し, 安静座位姿勢をとらせてから閉眼で実施 した（図 1 b)，試技開始位置はフットレストが移 動範囲の中心に位置する箇所とし, 膝関節屈曲 $60^{\circ}$ になるよう測定者が合わせた。試技開始後, 対象者 には, 測定装置によって膝関節屈曲方向へ他動的か つ周期的に加えられる力に対して, 釣り合いを保つ ように膝関節伸展方向へ力発揮をするように指示し た. 装置と対象者が出力する力の釣り合いがとれて いれば，足部位置とそれに伴う膝関節角度は変化し ないことになる。よって, 対象者の足部に対して測 定装置が加える力は, 釣り合いを取るために発揮す る力の目標值となる。

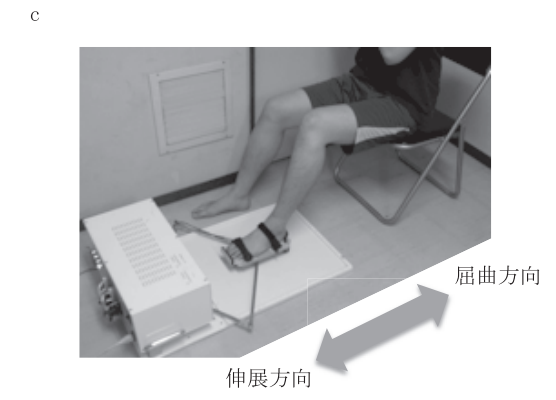

図 1 本研究で使用したデバイスおよび測定時の概観と測定によって得られるデー夕 $a ：$ ハプティックデバイス, b : 測定時の概観, c : 測定によって得られるデータ, d : 局面の分類. 
84 バイオメカニズム 22

この力の目標值を $10 \mathrm{~N}$ から $40 \mathrm{~N}$ の間で正弦波状 に変化するように設定した，装置が発生する正弦波 状目標值の周期は, 対象者の予測を制限するため, 分析対象とした 18 秒周期と，それに近い周期であ る 12 秒および 15 秒周期の 3 種類を混合した。つま り, 試技 1 回分の波形は, 18 秒周期 2 回と他の 2 種類の周期を組み合わせ, 計 4 つの波形で構成され るように設定した（図 1 c)，3 種類の周期の組み合 わせはランダムとした。

測定に先立ち, 上述の運動様式に慣れるために練 習試技を 2 回行った。試技開始および終了の合図は 測定者が口頭で行った． 1 試技に要する時間は約 1 分間であり，試技回数は 5 回とした.

デー夕解析は，金子らの報告を参考にした ${ }^{7)}$. 解 析対象とした周期 18 秒において, 目標力の漸増局 面と漸減局面別（図 $1 \mathrm{~d}$ ) に足部位置の平均移動距 離 $[\mathrm{mm}$ をを算出した。

\section{3 統計処理}

デー夕解析によって得られた值から, 対象者全員 の平均值土標準偏差を算出した。統計処理には統計 処理ソフト（SAS 社製，StatView 5.0）を用いた。 局面要因 (漸増局面, 漸減局面) と群要因（運動群, 対照群）からなる反復測定による二元配置分散分析 を行った。事後検定として Tukey-Kramerの多重 比較検定を行った，統計的有意水準は $5 \%$ とした.

\section{4 結果}

図 2 は, 各局面における群別の移動距離の結果で ある。局面要因と群要因による二元配置分散分析の 結果，交互作用が認められた $(p<0.05)$. 事後検定 の結果, 漸減局面において対照群が運動群に比べて 有意に高值を示した（移動距離：図 $2, p<0.05 ）$. 対照群では漸減局面が漸増局面に比べて有意に高值 を示した $(p<0.05)$ ，その一方で，運動群では局面 間に有意な差は認められなかった。

\section{5 考察}

局面要因と群要因による二元配置分散分析で交互 作用が認められ，事後検定の結果，対照群は漸減局

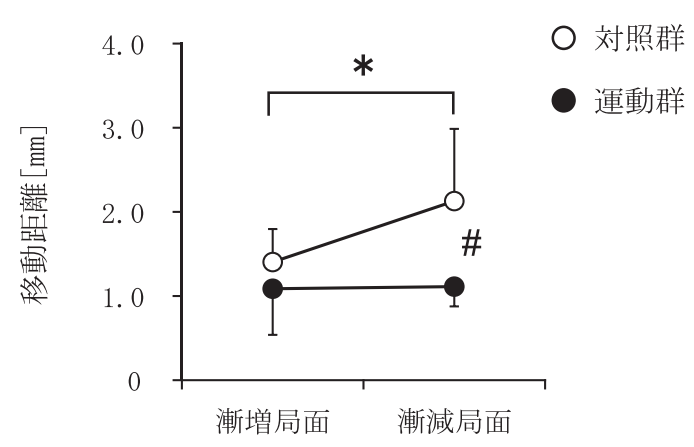

図2 各局面および各群における運動平衡保持課題による測 定結果（＃：群間で $p<0.05 ， *$ : 期間前後で $p<0.05 ）$

面が漸増局面に比べて有意に高值を示した（図 2, $p<0.05)$ ．この結果は，漸増局面より漸減局面にお いて受動負荷との釣り合いを保てなかったために, 足部位置の移動距離が増加したことを示唆しており、 課題の難易度は漸減局面が高いものと推察される.

これまで，等尺性収縮課題を用いた筋出力の増減 時には, 漸減局面において困難さが増すことが報告 されている ${ }^{18)}$. 一方で, 本研究のように受動的に加 わる負荷の漸増と漸減局面における運動調節を行っ た際の相違を明らかにした報告はこれまでになく, 新たな知見であるといえる。また，目標力の漸増局 面と漸減局面とで異なる結果を示した要因としては, 感覚機能, 運動機能, 両機能の連関としての上位中 枢活動の影響が考えられる.

まず，感覚機能の影響について述べる，運動感覚 は力や張力に関する感覚と, 関節位置や四肢の動き に関する感覚の統合的な感覚であるとされている ${ }^{1)}$ 目標力の時間変化は両局面で同一であるため, 運動 感覚として知覚される力の程度が影響したとは考え にくい，その一方で, 関節位置や動きの感覚は, 筋 の収縮から弛緩, 弛緩から収縮とで異なると指摘さ れている ${ }^{19,20)}$. したがって, 膝伸筋群や屈筋群共の 収縮動態が局面間で異なっていたことが影響を及ぼ したものと考える.

次に, 運動機能の影響について述べる. 筋出力発 現の最終経路である $\alpha$ 運動神経の興奮性は, 運動単 位の発射頻度と動員数に反映される ${ }^{2)}$. 低強度の筋 力調節では, 運動単位動員数の増減が筋出力調節に 関与し, 運動単位の動員停止は動員開始よりも低い 
強度で生じることが知られている ${ }^{10 \sim 12)}$ 。これらの ことから，漸減局面では動員された運動単位が活動 停止せずに活動し続けていたことで過剩な筋出力が 生じ, 結果として装置から加わる力と対象者が発揮 した力との誤差が生じた可能性がある。さらに，錘 外筋の収縮に伴って $\gamma$ 運動神経は筋紡錘を収縮させ, 内在する筋紡錘の弛緩による感度の低下を防ぐ 2 $(\alpha-\gamma$ 連関 $)$ 。このような神経生理学的要因が影響 している可能性も考えられる。 今後は, 筋電図計測 を行い，局面間で筋活動動態を比較する必要がある。 最後に，上位中枢活動の影響について述べる． TMS を用いた先行研究に扔いて, Rosenkranz et al.（2007）は, 非日常的で器用さの要求される運動 を常日頃実施している者は健常成人と比べて皮質脊 髄路の興奮性が高いことを示し ${ }^{21)}$, Nordstrom \& Butler（2002）は，その要因として皮質内抑制が軽 減することを示している ${ }^{22)}$. 運動平衡保持課題の漸 減局面で必要とされる運動調節が非日常的なもので あり，刘照群が漸減局面で上位中枢の興奮性が低い と仮定するならば，運動群は皮質脊髄路の興奮性を 必要とされる水準で維持していた可能性が考えられ る.これらのことから, 目標力が同一であっても, 局面によって（漸増か漸減か）感覚情報の量や中枢 で感覚情報を統合した結果としての興奮性が異なる ことなどが，本研究に扔いて局面間の相違を示した 結果に関連しているものと推察される.

さらに, 漸減局面においてのみ運動群と対照群と の間に有意な差が認められた（図 $2, p<0.05$ )。本 研究の結果は, 先行研究の結果の妥当性を高めるも のであり, あらためて, 運動平衡保持課題による測 定結果に漸減局面の差が影響する可能性 ${ }^{17)}$ が考えら れた，したがって，運動平衡保持課題による体性感 覚-運動連関機能の測定評価は, 目標力の漸増局面 と漸減局面とに分類することで，より詳細且つ明確 になると考えられる。

\section{3. 運動平衡保持課題を用いた練習効果の 検証（検討課題 2)}

\section{1 対象者}

対象者は，下肢に整形外科的および神経科学的既 往がなく，これまでに専門レベルでの運動歴を有さ

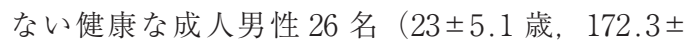
$4.1 \mathrm{~cm}, 69.3 \pm 6.7 \mathrm{~kg})$ であった。 そのうち, 運動 平衡保持課題を用いた運動介入を 3 日間連続して行 った 13 名を短期群とし, 介入を 1 ケ月行った残り の 13 名を中期群とした。なお，検討課題 2 の対象 者は, 検討課題 1 と重複していない者とした。検討 課題 1 と同様に, 測定内容については，測定を実施 した産業技術総合研究所内の倫理委員会で承認を得 た後，対象者から書面で同意を得た。

\section{2 運動平衡保持課題の実施手順及び解析項 目}

運動平衡保持課題の実施手順および解析項目は, 2.2 と同一であり, 漸増と漸減に分類した位置デー 夕を基に，移動距離を算出した。

\section{3 感覚機能の測定手順および解析項目}

感覚機能の測定には, 先行研究で多く採用され, 我々もこれまでに実施している運動検出課題 ${ }^{8.9)}$ 用いた。他動運動実施可能な装置（Cybex770NORM）を用い，座位姿勢で実施した。対象者の 下腿全体を覆うようにエアキャスト（FERNO JAPAN 社製，Model663）を取り付け，触覚や圧覚 などの感覚入力を制限した。また，装置の稼働音等 を遮断するために対象者にはヘッドフォンを装着さ せた，試技開始肢位は膝関節屈曲 $60^{\circ}$ とした，測定 の手順として，最初に対象者には準備の合図で閉眼 し脱力するよう指示した。 そして, 開始の合図の数 秒後に関節角度が他動的に変化 $\left(1^{\circ} / \mathrm{sec}\right)$ するので, 膝関節角度の変化とその方向を知覚した時点でレー ザーセンサー（KEYENCE 社製，LV-S61）によっ て合図するよう指示した。準備, 開始および終了の 合図は全て測定者が口頭で行った。試技回数は伸展 
86 バイオメカニズム 22

および屈曲方向を 3 回ずつ, 計 6 回とした。なお, 対象者の予測による反応を制限するため, 関節角度 が変化する方向の順序はランダムとした.

関節角度に関するデータは, 測定装置からアナロ グ信号として出力し, 高域カットオフ $10 \mathrm{~Hz}$ に設定 した外部フィルタ（共和電業社製，LF-303A）か ら A/D 変換器 (National Instruments 社製, BNC2110）を介してパーソナルコンピュータに取 り込んだ。また，対象者が使用するレーザーセンサ 一からの信号もパーソナルコンピュータに取り込ん だ.サンプリング周波数は $1000 \mathrm{~Hz}$ とした.

対象者がセンサーを用いて合図した時点の膝関節 角度と試技開始角度である膝関節屈曲 $60^{\circ}$ との差か ら算出し，運動検出闇值 [deg] とした。伸展，屈 曲方向について 3 試技分の平均值を算出した.

\section{4 運動機能の測定手順および解析項目}

運動機能の測定には，一定の力を等尺性収縮で維 持する課題 (以下, 発揮力一定課題) を実施した. 等尺性筋力測定装置（OG 技研社製，ハイドロマス キュレーター）を用い，座位姿勢で行った。対象者 が発揮する力の目標值は, 運動平衡保持課題で装置 から呈示される力の最大值との整合性を図り, 膝伸 展力 $40 \mathrm{~N}$ とした。モニタに目標值を表示し，でき る限り正確に目標值となる膝伸展力を維持するよう 指示した，膝伸展力のデータは，アンプ (共和電業 社製，YB504A）によって増幅しアナログ信号とし て出力した. サンプリング周波数は $1000 \mathrm{~Hz}$ とした 試技回数は 5 回とした.

各対象者に扮ける 1 試技毎に $40 \mathrm{~N}$ を一定に保っ ている間の力波形について標準偏差を算出し， 5 試 技分の平均值を運動出力機能の評価項目である力発 揮動摇 $[\mathrm{N}]$ とした.

\section{5 スケジュール}

実施したスケジュールを表 1 に示す、短期群の反 復回数は, 1 日目が 15 回, 2 日目が 20 回, 3 日目 が20回であった。また, 反復試技の前に, 練習試 技を連日 2 回行った。中期群は, 1 日 20 回の反復 を週 2 回の頻度で 1 ケ月間（4 週間）行った。両群
表 1 練習期間のスケジュール

\begin{tabular}{cccc}
\hline 群 & 期間 & 頻度 & 反復回数 \\
\hline 短期群 & 3 日間 & 3 日間連続 & $\begin{array}{r}1 \text { 日目 }: 15 \text { 日回 } \\
3 \text { 日目 }: 20 \text { 回 }\end{array}$ \\
中期群 & 1ヶ月間 & 週2回 & 20 回 \\
\hline
\end{tabular}

ともに, 運動平衡保持課題の実施については, 1 日 目と最終日の 5 試技の測定デー夕を解析に使用した 1 日目の最初の 5 試技を練習前, 最終日の最後の 5 試技を練習後の実施成績として解析した。運動検出 閾值, 力発揮動摇の測定は, 練習介入前の前日およ び介入後の翌日に行った。

\section{6 統計処理}

デー夕解析によって得られた值から, 対象者全員 の平均值土標準偏差を算出した。統計処理には統計 処理ソフト（SAS 社製，StatView 5.0）を用いた. 両群共に, 介入期間前後に扔ける運動平衡保持課題 による測定結果に関して，局面間の相違による変化 を, ステージ要因 (介入前および介入後), 局面要 因 (漸増局面および漸減局面), 群要因（短期群お よび中期群）の 3 要因からなる三元配置分散分析を 行った。感覚機能の測定結果は, ステージ要因, 群 要因からなる二元配置分散分析を行った。運動機能 の測定結果に関しても, ステージ要因と群要因から なる二元配置分散分析を行った。いずれの統計処理 に拈いても, 事後検定として Tukey-Kramer の多 重比較検定を行った。また, 全ての項目で介入前の 実施成績を 100 \%として, 介入後の実施成績を相対 值で変化率として算出し, 運動平衡保持課題の実施 成績の変化率と運動検出課題および発揮力一定課題 の実施成績の変化率との関係性について, ピアソン の積率相関係数を算出した，統計的有意水準は $5 \%$ とした。

\section{7 結果}

\subsection{1 運動平衡保持課題の実施成績の変化}

図 3 は, 介入前後での運動平衡保持課題における 生データの典型例である. 介入前後を比較すると, 視覚的に見て全体的に目標值との釣り合いがとれる 
（7） ハプティックデバイスを用いた下肢の体性感覚-運動連関機能の評価 87

ようになり，足部位置の移動が少なくなっているこ とがわかる。

ステージ要因, 局面要因, 群要因による三元配置 分散分析の結果，ステージ要因と局面要因との間に 交互作用が認められた $(p<0.05)$ ，そのため，事後 検定は短期群および中期群のデー夕を統合して行っ た（図 $4 \mathrm{a}$ )。事後検定の結果，漸増局面，漸減局面 ともに練習期間後で有意に低值であった $(p<0.05)$. また, 介入前では漸減局面が漸増局面に比べて有意 に高值を示していた $(p<0.05)$ が, 介入後では局 面間に有意な差は認められなかった。

群要因に有意な主効果は認められなかった一方で, 各群における各局面の変化率について群間で対応の ない $\mathrm{t}$ 検定を行ったところ, 漸減局面において中期 群が短期群に比べて有意に低值であった。また，漸
減局面では中期群の方がより変化率が大きいことが 示された（図 $4 \mathrm{~b}, p<0.05)$.

\section{7 .2 感覚機能および運動機能の変化}

図 5 a に, 感覚機能（運動検出閾值）の測定結果 を示す。運動方向の影響は認められなかったため, 伸展および屈曲方向の平均值で表している，ステー ジ要因と群要因による二元配置分散分析の結果, ス テージ要因に有意な主効果が認められ，介入後で闇 值が減少していたことが示された $(p<0.05)$.

図 $5 \mathrm{~b}$ に, 運動機能（力発揮動摇）の測定結果を 示す. ステージ要因と群要因による二元配置分散分 析の結果, 交互作用が認められ, 事後検定の結果, 中期群の介入後が介入前に比べて有意に低值を示し た $(p<0.05)$.

表 2 に, 各群における運動平衡保持課題の実施成 a
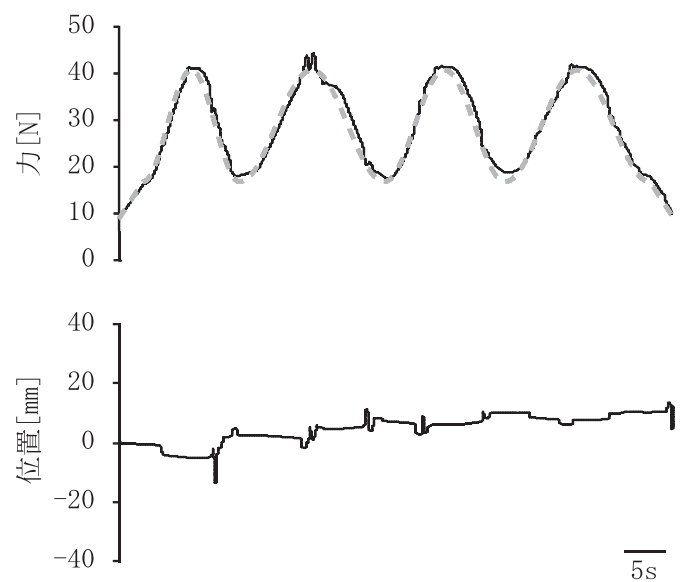

b
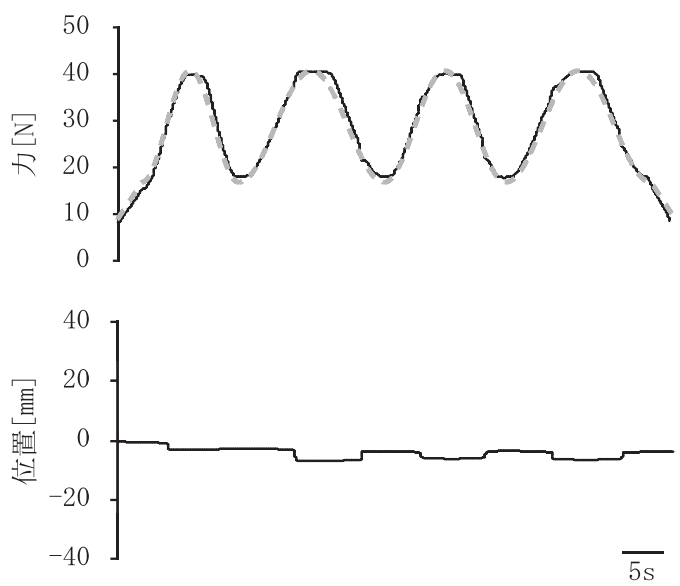

図 3 練習介入前後における中期群の生波形の典型例（a：練習期間前， b : 練習期間後）
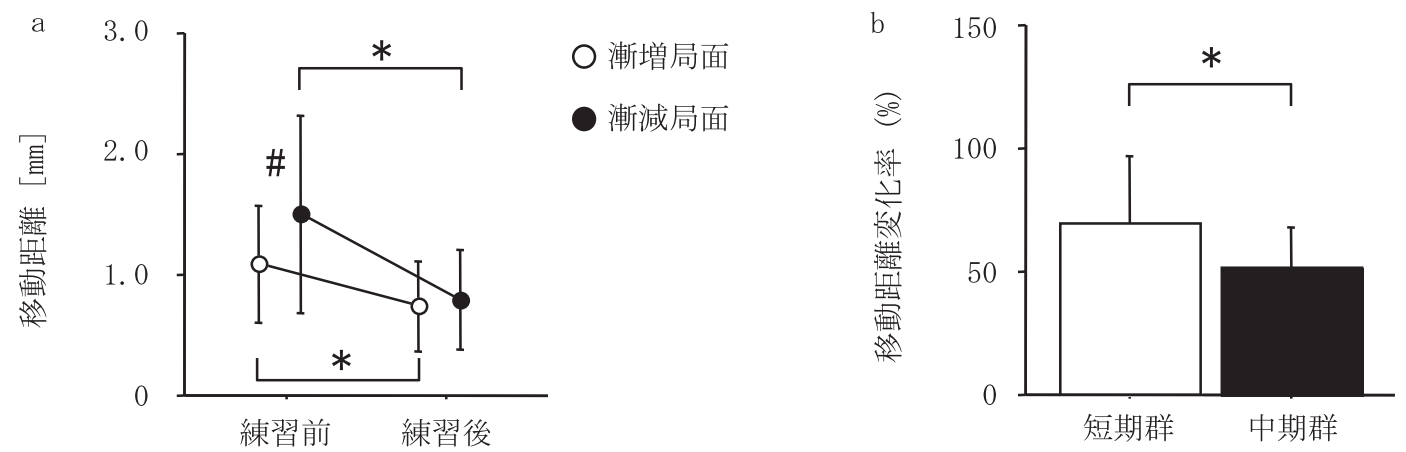

図 4 練習介入前後に打ける測定結果の変化. $\mathrm{a}$ ：運動平衡保持課題による測定結果（＃：局面間で $p<0.05, *$ ：練習介入前後で $p<0.05), \mathrm{b}$ : 練習介入前から後への変化率における群間の相違 $(*$ : 群間で $p<0.05)$. 

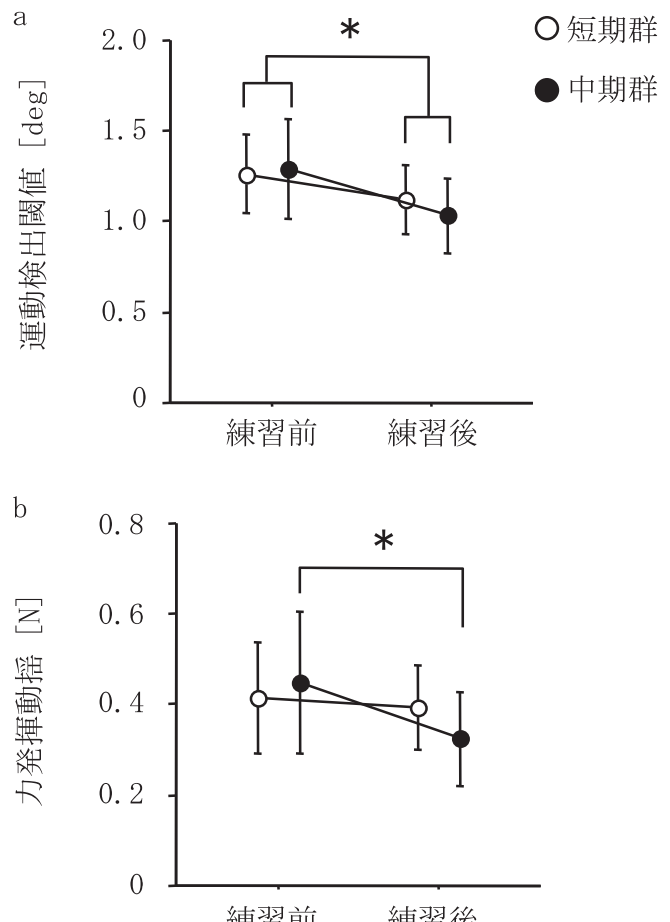

図 5 練習期間前後における感覚機能（a）および運動機能 (b) の変化 $(*: p<0.05)$

績の変化率と運動検出課題および発揮力一定課題の 実施成績の変化率との相関係数を示す.

運動平衡保持課題による測定結果と運動検出闇值 との相関係数は, 短期群が $r=0.816 \quad(p<0.05)$ で あり, 中期群が $r=0.670(p<0.05)$ であった.

運動平衡保持課題による測定結果と力発揮動摇で は，短期群で有意な相関関係が認められなかった。 中期群では, $r=0.581 （ p<0.05 ）$ であった.

\section{8 考察}

\subsection{1 運動平衡保持課題による測定結果における 介入効果の検出}

運動平衡保持課題による測定結果を練習介入前後 で比較した結果，両群ともに，漸増局面および漸減 局面共に介入後で有意に低值を示し（図 $4 \mathrm{a}, p<$ 0.05), 移動距離が減少していた。群間に差が認め られなかった要因としては, 短期間では運動学習効 果による即時的な結果の向上が生じた可能性が考え られる。また，漸減局面の介入前を $100 \%$ としたと
表 2 運動平衡保持による測定結果と感覚機能および運動機 能との相関係数 $\left(^{*}: p<0.05\right)$

\begin{tabular}{cccc}
\hline & & 運動検出閾值 & 力発揮動摇 \\
\hline 短期群 & 移動距離 & $0.816^{*}$ & -0.039 \\
中期群 & 移動距離 & $0.670 *$ & $0.581 *$ \\
\hline
\end{tabular}

きの介入後における変化率は，中期群の方が大きか った（図 $4 \mathrm{~b}, p<0.05)$. したがって，今後は残存 効果を調べて行くことで, 期間の相違による練習効 果の相違について検証する必要がある、いずれにし ても, 本研究の結果は, 少なくとも 1 ケ月以上反復 することで, 漸減局面で練習効果が生じることを示 唆している. 先の検討課題 1 では, 運動群と対照群 との差が漸減局面において認められた。そのため, 運動平衡保持課題の練習効果を検出する場合には, 局面間の相違が認められなくなる点に着目する必要 がある可能性を考察した。本検討課題の結果はその 仮説を支持するものであり, 運動平衡保持課題によ る測定結果を定期的に評価する場合，局面間の相違 が認められなくなることに加えて, 漸減局面の変化 率に着目する必要があるものと推察する.

\subsection{2 介入前後における感覚機能および運動機能 の変化}

介入前後における感覚機能（運動検出闇值）掠よ び運動機能（力発揮動摇）の測定結果について, 各々ステージ要因と群要因による二元配置分散分析 を行った結果, 運動検出闇值ではステージ要因に有 意な主効果が認められた（図 $5 \mathrm{a}, p<0.05$ ). 力発 揮動摇では交互作用が認められ, 事後検定の結果, 中期群が介入前に比べて介入後で有意に低值を示し た（図 $5 \mathrm{~b}, p<0.05)$ 。これらの結果は, 今回対象 とした短期群と中期群とでは, 運動平衡保持課題の 練習による感覚機能と運動機能の変化の程度に相違 があることを示している，またこれらの結果は，運 動平衡保持課題を練習方法として用いた場合であっ ても, 感覚機能および運動機能の向上が期待できる 可能性を示している。，その場合，中期群においては， 感覚機能と運動機能の双方が向上していたことから， 少なくとも1 1 ケ月程度の練習期間後で両機能の向上 が期待できるものと推察される. 事実, 先行研究で 
は, 短期間での急性的効果も含め, 感覚入力機能や 運動出力機能は 1 ケ月程度の間に向上することが報 告されている ${ }^{15,16)}$. 本研究課題の結果もそれら先行 研究を支持するものとなり得るが, 介入方法として の確立をするためには，残存効果等を検討する必要 があるため, 今後の課題としたい.

運動平衡保持課題による測定結果の変化率と運動 検出闇值および力発揮動摇の変化率について相関係 数を算出した結果, 運動検出閾値の変化率との関係 性について, 短期群および中期群ともに有意な相関 関係が認められた（短期群 $: r=0.816, p<0.05$, 中期群 : $r=0.670, p<0.05$, 表 2$)$. これらの結果 は, 両群ともに運動平衡保持課題を用いた練習によ って移動距離が減少するだけでなく，感覚機能も向 上したことを示している，運動検出閾值は筋紡錘の 伸張によって生じる I a 群神経を伝播する求心性入 力状況に対する応答であるとされている ${ }^{23)}$. 筋紡錘 は, $\gamma$ 運動神経を伝播する入力によって収縮レベル が異なり， $\gamma$ 運動神経は上位中枢の興奮性に影響さ れることを検討課題 1 の考察で述べた。この上位中 枢の興奮性に関して, Perez et al. (2004) は, 1 日 以内の運動技能トレーニング (motor skill training）であっても，皮質脊髄路の興奮性が増加する ことを明らかにした ${ }^{24)}$. 運動平衡保持課題も, 課題 遂行の目的を考えるとある種の運動技能トレーニン グであり, 実施成績の変化から課題の介入効果はあ ったと判断できる. 以上のことから, 本研究課題に おいては 3 日間などの短期間であっても, 少なくと も皮質脊髄路の興奮性は増加し, 筋紡錘の収縮レベ ル，すなわち感度が向上することで運動検出閾值が 向上したのではないかと推察される.

力発揮動摇の変化率との関倸性については, 短期 群では有意な相関関係は認められず, 中期群におい て有意な相関関係を示した $(r=0.581, p<0.05$, 表 2)。これらの結果は, 中期群において移動距離 の減少と感覚機能の向上のみならず, 運動機能 (力 発揮動摇）も向上したことを示している. その要因 としては, 運動の繰り返しによって中枢機能に適応 が生じたことによる, 運動単位の動員や発射頻度の 変化が寄与しているのではないかと考えられる ${ }^{25)}$.
一方で, 短期群で有意な向上は認められなかった。 このことから, 運動機能を向上させるためには, 少 なくとも 4 週間の期間を要するものと推察する.

以上のように, 運動検出閾值と力発揮動摇ともに 運動平衡保持課題による測定結果との間に有意な関 係性を示したことは，短期間では感覚機能が向上し， 中期間では感覚機能に加えて運動機能も向上するこ とを示唆している. 運動平衡保持課題は, 目標力が 常に変化する運動調節課題である。したがって, 制 御理論的に考えると運動平衡保持課題の実施におけ る運動調節は閉回路制御である。閉回路制御では, 感覚情報に基づいて目的とする運動の結果と実際の 運動の結果との誤差を検出し, その誤差を低減する ために運動プログラムを修正，実行する ${ }^{26)}$ 。短期群 では感覚入力機能のみが向上し, 運動平衡保持課題 の変化率とも相関関係があったことから, 短期間で は実際の運動の結果を運動感覚情報によって正確に 把握するよう留意しており, その結果, 感覚入力機 能が向上したものと考えられる。 そして, 中期間で はある程度正確に身体状況を把握できるようになり， 運動平衡保持課題の課題遂行に関係する安定した力 発揮（力発揮動摇）を実現しようとしていたことが 考えられる。したがって, 中期間では運動検出闇值 の向上に加えて, 力発揮動摇の向上が認められたと 推察される。ただし, 本研究課題では短期群が毎日 介入を行っていたのに対し, 中期群は週 2 回の実施 頻度であった。 そのため, 介入の実施頻度によって 感覚入力機能と運動出力機能に及ぼす影響が異なる 可能性も否定できない，本研究は評価法としても検 討を行うものであるが, 今後, より効果的な練習方 法としての検討を行う場合, この点を明らかにして 行く必要がある。

\section{4. まとめ}

本研究では, ハプティックデバイスを用いた運動 平衡保持課題について, 体性感覚 - 運動連関機能の 測定評価方法としての有用性と, 練習効果の検証を 行った。明らかとなったことは, 以下のとおりであ る. 
（1）運動平衡保持課題の実施成績について，装置 から呈示される目標力の漸増局面と漸減局面別に比 較するとともに，運動歴の差異が及ぼす影響につい て検討した。 その結果, 日頃運動を行っていない者 は漸減局面が漸増局面に比べて有意に高值を示した その一方で, 運動群は局面間の相違が認められなか った。また, 漸減局面に扔いて, 運動群と対照群と の間に差異が認められた。これらのことから，体性 感覚 - 運動連関機能の測定評価を行う場合は, 漸減 局面に着目する必要があると考えられた。

（2）運動平衡保持課題を練習方法として用い，短 期的および中期的な練習効果として測定結果が向上 した場合，それに伴って感覚機能㧍よび運動機能が どのように変化するかについて調べた。

その結果, 短期群, 中期群共に, 運動平衡保持課 題による測定結果が有意に向上し，局面間の相違が 認められなくなった。 また, 漸減局面における練習 期間前後の変化率は, 中期群が短期群に比べて有意 に高值を示した。さらに, 感覚機能は, 短期群, 中 期群共に有意に向上し, 運動機能は, 短期群では変 化がなく, 中期群で有意に向上した。これらのこと から, 運動平衡保持課題による測定結果の向上は, 局面間の相違が認められなくなることに加えて, 漸 減局面の変化率に着目することでより詳細な練習効 果を検出できる可能性が示された。また，運動平衡 保持課題の練習効果として, 感覚機能および運動機 能も向上することが示唆された。

\section{参考文献}

1) Gandevia, S, C.: Kinesthesia: roles for afferent signals and motor commands. In: Rowell, B, L., Shepherd, T, J. (Eds) : Handbook of physiology, Section 12 : Exercise: regulation and integration of multiple systems, 128-182, Oxford University Press, New York, (1996).

2) Pearson, K., \& Gordon, J.: Spinal reflex In., Kandel, E. R., Schwartz, J. H., \& Jessell, T. M. (Eds) : Principles of Neural Science, 4 th Ed, (2000).

3）岩村吉晃：タッチ. 医学書院, 東京, 115-146, (2001).

4) Sariegna, F, R., Gauthier, G. M., Gourdin, C., Vercher, J, L., \& Blouin, J.: Internally driven control of reaching movements: a study on a proprioceptively deafferented subject. Brain Res Bull 69, 404-415, (2006).

5）岩田洋夫：体性感覚呈示技術. バイオメカニズム学会誌, 31, 78-81, (2007).

6) 金子文成, 速水達也, 木塚朝博, 横井孝志 : 力平衡保持
課題による感覚-運動連関機能評価の試み. 体力科学, 53, 650, (2004).

7）金子文成, 速水達也, 浅井義之, 横井孝志, 木塚朝博 : 体性感覚-運動連関機能を運動平衡保持法で評価するた めの指標について. 第 21 回生体・生理工学シンポジウ 么論文集, 259-260, (2006).

8）金子文成, 速水達也, 横井孝志, 木塚朝博 : 能動的知覚 に応じて出力する運動課題実施成績の評価指標に関する 研究一反復練習効果の検出から一. 理学療法学, 36 , 9-17, (2009).

9）速水達也，金子文成，木塚朝博：運動経験による体性感 覚-運動連関機能の相違．バイオメカニズム 19，47-56, (2008).

10) De Luca, C, J., LeFever, R, S., McCue, M, P., \& Xenakis, A, P.: Behaviour of human motor units in different muscle during linearly varying contractions. J Physiol 329, 113-128, (1982).

11) Romaiguere, P., Vedel, J, P., \& Pagni, S.: Comparison of fluctuations of motor unit recruitment and $\mathrm{de}^{-}$ recruitment thresholds in man. Exp Brain Res 95, 517-522, (1993).

12) Gorassini, M., Yang, J, F., Siu, M., \& Bennett, D. J.: Intrinsic activation of human motoneurons: possible contribution to motor unit excitation. J. Neurophysiol, 87, 1859-1866, (2002).

13) Kimura, T., Yamanaka, K., Nozaki, D., Nakazawa, K., Miyoshi, T., Akai, M., \& Ohtsuki, T.: Hysteresis in corticospinal excitability during gradual muscle contraction and relaxation in humans. Exp Brain Res 152, 123-132, (2003).

14) Eils, E., \& Rosenbaum, D.: A multi-station proprioceptive exercise program in patients with ankle instability. Med Sci Sports Exerc 33, 1991-1998, (2001).

15) Bouët, V., \& Gahéry, Y. : Muscular exercise improves knee position sense in humans. Neurosci Lett 289, 143-146, (2000).

16) Hart, C, E., \& Tracy, B, L.: Yoga as steadiness training: effects on motor variability in young adults. J Strength Cond Res 22, 1659-1669, (2008).

17）速水達也, 金子文成, 横井孝志, 木塚朝博：運動平衡保 持課題による受動負荷の漸増と漸減局面における下肢運 動調節の評価. 体力科学, 59, 207-214, (2010).

18) Spiegel, K, M., Stratton, J., Burke, J, E., Glendinning, D, S., \& Enoka, R, M.: The influence of age on the assessment of motor unit activation in a human hand muscle. Exp Physiol 81, 805-819, (1996).

19) Wise, A, K., Gregory, J, E., \& Proske, U.: The effects of muscle conditioning on movement detection thresholds at the human forearm. Brain Res 735, 125-130, (1996).

20) Rymer, W.Z., D’Almeida, A.: Joint position sense: the effects of muscle contraction. Brain 103, 1-22, (1980).

21) Rosenkranz, K., Williamon, A., Rothwell, J, C.: Motorcortical excitability and synaptic plasticity is enhanced in professional musicians. J. Neurosci, 27(19), 52005206, (2007).

22) Nordstrom, M, A., \& Butler, S, L.: Reduced intracortical inhibition and facilitation of corticospinal neurons 
in musicians. Exp Brain Res 144, 336-342, (2002).

23) Lephart, S, M., Giraldo, J, L., Borasa, P, A., \& Fu, F H.: Knee joint proprioception: a comparison between female intercollegiate gymnasts and controls. Knee Surg Sports Traumatol Arthrosc 4, 121-124, (1996).

24) Perez, M, A., Lungholt, B, K., Nyborg, K., \& Nielsen, J, B.: Motor skill training induces changes in the excitability of the leg cortical area in healthy humans. Exp
Brain Res 159, 197-205, (2004).

25) Tracy, B, L., Byrnes, W, C., \& Enoka, R, M.: Strength training reduces force fluctuations during anisometric contractions of the quadriceps femoris muscles in old adults. J. Appl Physiol 96, 1530-1540, (2004).

26) Schmidt, R, A.: Motor Control and Learning : A Behavioral Emphasis. Champaign, IL, Human Kinetics, 482-489, (1982).

\title{
Evaluation of Somatosensory-Motor Integration Function by means of Haptic Device
}

\author{
Tatsuya HAYAMI ${ }^{1 \dagger}$, Fuminari KANEKO ${ }^{2}$, Takashi YOKOI $^{3}$, Tomohiro KIZUKA ${ }^{4}$ \\ ${ }^{1}$ Shinshu University, ${ }^{2}$ Sapporo Medical University, \\ ${ }^{3}$ National Institute of Advances Industrial Science and Technology, ${ }^{4}$ University of Tsukuba
}

\begin{abstract}
In the present study, we defined the ability of motor control based on the somatosensory input as a somatosensory-motor integration function, and performed a motor task termed as the kineticequilibrating task to evaluate this function. The kinetic-equilibrating task was performed by using a haptic device. The subjects were instructed to maintain their limb position against the passive force, and the change in the limb position was recorded. The recorded values were compared in the ascending and descending phase of the passive force. In addition, the influence of the duration of the subjects' sports career on the recorded values was examined. The results indicated that maintain the limb position was more difficult than in the ascending phase of the passive force, and a marked influence of the duration of the subjects' sports career was showed in the descending phase. Moreover, by using a kinetic-equilibrating task, we verified the practice effect on the somatosensory-motor integration function, motor function (fluctuation of force production), and sensory function (detection threshold of movement). Furthermore, the values recorded during the kinetic equilibrating task in the ascending and descending phases had both improved after the practice period. In addition, the motor function and sensory function had also improved after the practice period. Thus, the current findings confirmed the validity of using the kinetic-equilibrating task, involving a haptic device, for the evaluation of somatosensory-motor integration function. These results suggested that the task was a very useful practice method for improving somatosensory-motor integration function, motor function, and sensory function.
\end{abstract}

Key Words: somatosensory-motor integration function, kinetic-equilibrating, motor function, sensory function

\footnotetext{
† Shinshu University, Asahi 3-1-1, Matsumoto City, Nagano 390-8621 Japan, Tel: 0263-37-2957, E-mail: hayamit@shinshu-u.ac.jp
} 